\title{
An Independent Audit Oversight System in a Developing Country
}

\author{
MAZLINA MUSTAPHA ${ }^{1}$, LIM YAN KONG ${ }^{2}$ \\ ${ }^{1}$ School of Business and Economics, UNIVERSITI PUTRA MALAYSIA, MALAYSIA \\ Email: mazlina05@gmail.com \\ ${ }^{2}$ School of Business and Economics, UNIVERSITI PUTRA MALAYSIA, MALAYSIA \\ Email: limyankong@gmail.com
}

\begin{abstract}
Audit Oversight Board (AOB) was established in Malaysia to regulate the auditors of public listed companies and instil the trust and confidence of the public on the quality of audit services provided by them. This study aims to explore the impact of $A O B$ establishment on external auditors. Interviews were conducted with twenty audit seniors and managers in Big four and non-Big four firms in Klang Valley. The interviews revealed that more works were done and more documentation was compiled after $A O B$ establishment. The results also indicated that more informal meetings were conducted to get more information and clarification from the clients to solve audit issues. However, the auditors claimed that their reliance on the internal auditors was not affected by $A O B$ establishment. The findings also suggested that audit fee was not directly affected by the establishment of $A O B$. The results of the study contribute to the literature and understanding of $A O B$ establishment in Malaysian audit industry.
\end{abstract}

Keywords: Audit Oversight Board, External Auditor, Malaysia, Public interest.

JEL Classification: C99, L84, M42 


\section{Introduction}

It is reported that effective audit oversight is the most important element in upholding audit quality, and audit quality is the key in safeguarding public trust and strengthening investors confidence in ensuring reliable corporate reporting (Wan Hussin, 2018; AOB annual report, 2019). The famous Enron scandal in United States in 2001 has triggered the enforcement of law (Li, 2010). The world witness a shift in accounting and auditing system, from privately organised self-regulation to increased public oversight (Alon, Mennicken and Samsonova-Taddei, 2019). After several major corporate and accounting frauds (such as WorldCom, Parmalat, Adelphia), United States has enacted Sarbanes-Oxley Act and established Public Company Accounting Oversight Board (PCAOB) to protect the interest of investors and the public by overseeing the audit procedure of audit firms (PCAOB, 2011). In line with the establishment of global regulatory bodies in protecting public interest and promoting the accountability of auditors, necessary actions are also taken by Malaysian government to enhance the accountability of audited financial reports.

In Malaysia, Audit Oversight Board (AOB) was established in 2010 under the Securities Commission Act to foster the quality of independent audit in Public Interest Entities (PIEs) in Malaysia (AOB annual report, 2010, 2019). The establishment of AOB in Malaysia is giving effect on the audit profession. Auditors are being overseen by $A O B$ to ensure their compliance with International Standards on Auditing (ISA) as well as the International Standard on Quality Control 1(ISQC1) (Wan Hussin, Bamahros and Shukeri, 2016; Enhancing Audit Quality, 2008). AOB can be viewed as a catalyst in identifying the weaknesses of the audit profession (Gomez, 2010). AOB has the right to inspect the work of auditors, to inquire them and to take action towards those who do not comply with the standards. It is claimed that the independent oversight of the AOB will definitely increase the quality of audit (Wan Hussin, 2018; Gomez, 2010).

After the establishment of $A O B$ in Malaysia, the impacts on the opinion given and audit work performed are inevitable as the audit profession is shifting from self-regulated to rules-regulated (Alon et al., 2019; Gramling, Krishnan \& Zhang, 2011). Given the power by the Securities Commission Act, AOB has sanctioned several auditors after careful investigations due to their violation of MIA's By-laws and ISAs (AOB Annual Report, 2013, 2016, 2017, 2018, 2019). This is to encourage other auditors to abide by the standards and perform better. For example, in 2017, three independent auditors were reprimanded for breaching AOB's registration condition imposed under Section 310(4) of the Securities Commission Act 1993 (AOB Annual Report, 2017), and in 2016, four audit partners were referred to AOB's Enforcement Department for further action (AOB Annual Report, 2016).

It is also claimed that the cost of audit is bound to increase with the compliance cost to meet the expectation of AOB (Florou and Shuai, 2020; Sook- Hwa and Mustapha, 2015). Empirical study in U.S. found that the audit fee premium had increased especially during the first few years after the implementation of Sarbanes-Oxley (SOX) Act (Ebrahim, 2009). In relation to this, it is claimed that external auditors might rely more on the internal audit function, which helps to minimize the duplication of audit effort, and reduce the overall cost incurred (Bame-Aldred, Brandon, Messier, Rittenberg \& Stefaniak, 2013). Hence, this might be the scenario after the establishment of AOB which is claimed has increased the cost of compliance.

Prior studies pointed out that there are impacts of the establishment of audit oversight board on the auditors (Gramling, Krishnan \& Zhang, 2011; DeFond, 2009). However, there is limited study done on the impact of $A O B$ on the auditing and accounting profession in Malaysia. Hence, this study aims to explore the impact of the establishment of $A O B$ towards the auditing profession in Malaysia. The results of the study contribute to the literature and understanding of $A O B$ establishment in Malaysian audit industry. The findings also provide information and understanding to the preparers of financial statements on the importance and impact of audit done by $A O B$ on them and their auditors.

The paper is organized as follows. The next section discusses the relevant literature relating to audit oversight board around the world and in Malaysia, followed by research methodology and the results. The paper ends with the conclusion of the research. 


\section{Literature Review}

Public Company Accounting Oversight Board (PCAOB) was created under Sarbanes-Oxley Act 2002 to oversee the auditors of public companies, to protect the interest of investors and maintain the quality of audit (Florou and Shuai, 2020; Earwood, 2010). The establishment of PCAOB in the United States replaced self-regulation of the auditing industry which had lasted for over 50 years (Huang and Chong, 2016; DeFond, 2009; Hilary \& Lennox, 2005).

The establishment of PCAOB is perceived to be independent and also resolving the public's concern that the government is taking care on the issue of independence between practice and oversight (Bather \& Burnaby, 2006). In short, the U.S. government established PCAOB to encourage auditors to meet the expected quality, showing how the U.S. government response to the problem of fraud that would affect the confidence of investors in the capital market. After the establishment of PCAOB in U.S., other countries around the world also start to promote high quality audits of financial reports and raise the standard of conduct in the auditing profession by proposing audit oversight board in their countries (Huang and Chong, 2016, Khan et al., 2020). For instance, the Public Accountants Oversight Committee (PAOC) in Singapore, Audit Oversight Board (AOB) in Malaysia, the Australian Securities \& Investments Commission (ASIC) in Australia, European Group of Auditors' Oversight Bodies (EGAOB) in Europe, and Financial Reporting Council in the U.K.

\subsection{Establishment of Audit Oversight Board (AOB) in Malaysia}

After several financial scandals in Malaysia, the audit profession is experiencing a period of serious turmoil (Lee \& Ali, 2008). Hence, the plan to establish a Public Companies Accounting Oversight Board under the Securities Commission came out in 2007. Securities Commission set up a task force to come out with a framework that would be acceptable to all parties and later proposed the establishment of Audit Oversight Board and was approved by the Parliament (Gomez, 2010).

Audit oversight board was established in April 2010 under the Securities Commission Act 2010 to regulate the auditors of PIEs and protect investors' interest in the entities (AOB Annual Report, 2010). In the early stage, $A O B$ is concentrating on the registration of audit firms and auditors with $A O B$ and started to inspect the auditors in August 2010 (AOB Annual Report, 2010). AOB also engaged with various regulators which are Bank Negara Malaysia (BNM) and Companies Commission of Malaysia (CCM) to improve understanding on supervision of PIEs in areas that are relevant to AOB (AOB Annual Report, 2010). Later, AOB had joined the International Forum of Independent Audit Regulators (IFIAR) and Association of Southeast Asian Nations Audit Regulators Group (AARG) which allowed AOB to share knowledge and experience from audit regulators from all over the world to enhance their audit oversight activities (AOB Annual Report, 2012).

AOB aims to foster high quality independent auditing by enforcing the ISA, and ISQC 1 by imposing sanctions on the auditors who fail to comply with the standards. One of the main efforts done by AOB to promote high quality of audit is through inspection activities (AOB Annual Report, 2013, 2015, 2017, 2019). There are strict actions taken to audit firms or auditors who are auditing public interest entities and did not register themselves with the AOB. This is because non-registration is an offence and license will be revoked for these auditors as well as firms (Wan Hussin, 2018; Gomez, 2010). Hence, it is compulsory for all auditors who are auditing public interest entities to register with AOB.

\subsection{Effect of Establishment of Audit Oversight Board on external auditors}

Prior studies claimed that $A O B$ establishment affect the auditors and their audit works. Among others, it is posited that $A O B$ would affect the audit documentation, audit fees charged to the clients, the audit opinion given, the external auditors' reliance on internal auditors and their meetings with the clients.

Effort and risk adjusted fees will directly increase the quality of audit (Hoitash, Markelevich \& Barragato, 2007). Hence, it is expected that audit fees will increase to meet the objective of AOB which 
is to increase the confidence of public in the capital market by providing high quality audit (AOB Annual Report, 2013). Mitra, Deis \& Hossain (2009) found that the higher the audit and non-audit fee, the higher the quality of audit. This is because of the "reputation protection" argument that demonstrates higher audit fees are translated into greater audit engagement effort, which is greatly associated with audit quality.

In addition, one of the recurring findings in $\mathrm{AOB}$ annual reports is inadequate evidence collected by auditors to support their opinions (AOB Annual Report 2013, 2014). More audit evidences need to be collected in order to support the basis of audit opinion. In order to collect more evidences, more resources such as time and manpower need to be allocated, as more effort involved, more audit fees may be charged (Beck, Fuller, Muriel \& Reid, 2013). Simunic (1980) posited that quantity of auditing demanded would directly affect the costs and eventually the audit fee. This is supported by a recent study which claimed that audit costs increase for clients of inspected auditors due to more laborious, independent, and rigorous inspections are carried out (Florou and Shuai, 2020). Hence, audit fee is expected to increase in order to comply with the $A O B$ requirements.

After the establishment of $A O B$, it is also expected that the litigation risk is higher that causes the auditors to be more willing to provide a qualified audit report for financial distressed firms (Habib, 2013). According to Gramling, Krishnan \& Zhang (2011), when the independent regulatory body or the PCAOB indicated that there are more deficiencies in the firm, the external auditors tended to give a going concern opinion on the client with financial distress. This increase of litigation risk causing a rise in auditor conservatism in the issuance of unqualified audit reports (Stunda \& Pacini, 2013). It is claimed that the investors place more value in the unqualified audit report in a post-SOX period due to shift in auditor thresholds and litigation risks (Stunda \& Pacini, 2013), similar situation may occur after AOB establishment.

A study by Robertson \& Houston (2010) found that investors believed that the PCAOB inspection process improved the credibility of future audit opinions. Audit firms with PCAOB deficiencies would try to improve their credibility of future audit opinion when the audit firm responded to the deficiencies identified by PCAOB with a concession (Robertson \& Houston, 2010). Hence, audit opinion given by external auditors would be affected by the findings of inspection by PCAOB. It would be expected that findings on deficiencies of firms would encourage the firm to provide a credible audit opinion.

Prior to the enforcement of PCAOB, auditors tend to reduce their documentation as it will increase the efficiency and reduce the litigation risk (Levy, 2005; Payne \& Ramsay, 2008). This is because auditors found that it is costly to review the detailed working paper and this detailed working paper can be used by plaintiff against the auditor in the court of law in an attempt to demonstrate a pattern of negligence (Rich, Solomon \& Trotman, 1997). However, during inspections, PCAOB pointed out that audit working paper is the basis for the reviewer to evaluate the quality of work because it provides the reviewers with written documents and evidence supporting the conclusion given (Latshaw, 2004). Another study found that after $\mathrm{AOB}$ was established, the documentation and training costs of external auditors increase, but vary across audit firms of different sizes. This is due to the auditors trying to fulfil the requirements set by AOB (Sook-Hwa and Mustapha, 2015). PCAOB also requires auditors to prepare audit documentation in connection with the engagement according to the auditing standards (Latshaw, 2004). AOB's annual report 2012 and 2013 reported that there was insufficient audit evidence or inappropriate audit evidence in the working papers (AOB Annual Report, 2012; 2013). AOB also emphasised that it is urgent to improve on the deficiencies of the audit evidence to support the opinion given (AOB Annual Report, 2012). Hence, after the announcement of the deficiencies in audit engagements, the firms are expected to improve their documentation and to provide sufficient documentation to support their opinion.

External auditors can rely on the internal audit function of client during discharging of their duties when the internal audit activities meet certain criteria and the external auditors would find efficiencies in relying on their work (Bame-Aldred, Brandon, Messier, Rittenberg \& Stefaniak, 2013). Previous research found that external auditors' reliance on the internal audit function depend on the 
environment and risk on the client's organization (Bame-Aldred, Brandon, Messier, Rittenberg \& Stefaniak, 2013). After establishment of AOB, risk assessment process of auditors was expected to improve and indirectly would affect the reliance on internal audit function.

It is also found that negotiation between auditors and clients will result in congruence of the issues discussed (Gibbins, McCracken, Salterio, 2005). Auditor tends to be more conservative and increase the audit effort by increasing sample size if there is lack of negotiation between auditor and client (Antle \& Nalebuff, 1991). By discussing with client, auditors will have the chance to assess and understand the risk in the clients' organizations (Zimbelman \& Waller, 1999). After the establishment of $A O B$, auditors are expected to meet with their client more frequent to understand the environment of the organization. Auditors may also opt to reduce the cost by understanding the client organization through meeting with audit committee and related personnel in the organization.

\section{Methodology}

Primary data is employed to gather the data for this research. Qualitative approach is used to obtain information from external auditors on how establishment of $A O B$ affect their audit works. The key benefit of using qualitative research in this study is to allow researcher to observe and understand the context within which decisions and actions take place (Myers, 2009). Prior study claimed that decision made by the external auditors can only be best understood by talking to the related people, instead of gathering quantitative information (Myers, 2009).

The target interviewees are external auditors who are attached to the registered firms with $A O B$ and have at least two years of auditing experience. In addition, they must also have experience in auditing PIEs before and after the establishment of AOB. Thus, only auditors with senior associate position and above are chosen. External auditors are selected because they are directly monitored by $A O B$, thus they would get the greatest impact compared to other parties, such as internal auditors or accountants/ financial statement preparers.

In-depth interviews were conducted with twenty external auditors. Prior to the interviews, the samples chosen were contacted via telephone to obtain their agreement to participate in the interview. A semi-structured questionnaire was utilized as a guideline for the interview, where the questions were revolving on how $\mathrm{AOB}$ affect external auditors' works after its establishment. The data collection was done in January, February and March 2014. The interviews were transcribed and analyzed.

\section{Results and Discussion}

\subsection{Profile of respondents}

The demographic characteristics of the external auditors show that out of 20 interviewees, three of them are audit assistant manager and another seventeen are senior auditors. They were selected from audit firms in Kuala Lumpur and Selangor. Fifteen of them are male and five are female. All of them have more than two years' experience in the audit firm and have experienced auditing PIEs before and after the establishment of AOB. Fifteen of them have professional qualifications. Two of the assistant managers have more than 5 years of experience in external auditing. Ten of them are from Big Four audit firms and another ten are from medium and small audit firms. All the firms are registered with $\mathrm{AOB}$.

\subsection{Interview Results}

\subsubsection{How does $A O B$ affect audit profession?}

The external auditors were asked about how the establishment of $A O B$ affects the audit profession in general and the auditors' work in particular. Most of them think that establishment of AOB have an 
impact on the profession. Some respondents think that $A O B$ can help to instil the trust and the confidence of the public on the profession. They posit that:

"AOB ensures that the audit profession maintains its professionalism and standard so as to avoid any reduction of trust by the public." (Assistant Manager J)

" $A O B$ is successful in developing an effective audit oversight framework and provide the confidence to the public and investors on the quality and reliability of the audited financial statements in Malaysia." (Assistant Manager R)

Some of the respondents agreed that with the establishment of $A O B$, audit quality has improved. The responses from some of the respondents are as follows:

"AOB improves the quality of the audit profession. It gives a standard to the audit profession." (Senior Auditor N)

"AOB ensures a greater audit quality."( Senior Auditor $P$ )

"....Stringent audit requirement by $A O B$ brings higher quality audit." (Senior Auditor S)

"AOB is the quality controller of audit profession." (Senior Auditor D)

"Yes, ...as $A O B$ will audit the audit firm...need to ensure the audit procedures are performed well." (Senior Auditor H)

"Yes, with its establishment, quality is ensured further." (Senior Auditor T)

"...AOB is a watchdog to ensure audit profession is conducted according to standards and adheres to the highest level of professionalism of auditing" (Assistant Manager J)

The respondents stressed that AOB enforced the implementation of ISQC 1 by audit firms. Some of them admit that the inspection done by $A O B$ exerted some pressure on the auditors to perform their job according to the standards specified by the profession to ensure its quality, and those who did not comply may be given penalties. They commented that:

"....AOB has revoked multiple audit licenses of audit firms that have not been in compliance with auditing standard" (Senior Auditor T)

"...the deficiency highlighted by $A O B$ actually caused more work being done. This actually provides guidance for auditors on the area that they pay insufficient attention before...." (Senior Auditor E)

Overall, the respondents think that the establishment of $A O B$ have some impacts on the audit profession. The interviews reveal that the inspection activities done by AOB exert some pressure on audit firms to enhance their audit quality. Sanction and revocation of some audit licenses help to ensure the independence of the auditors and their compliance with the auditing standards.

\subsubsection{How does the establishment of $A O B$ affect the audit fee charged?}

The respondents were asked whether the audit fees charged to their clients were affected by the establishment of AOB. Most of the respondents explained that audit fee is based on combination of a few factors, such as size of the entity, total sales, total assets, complexity of the clients' operations and risks of the clients' businesses, but it is not affected by the AOB establishment. However, they admitted that if more works are done in order to ensure the requirements set in the standards as reviewed by $A O B$ are achieved; more fees will be charged to the clients. And they also agreed that after the establishment of $A O B$, their workload has increased. They commented that:

"Requirements of $A O B$ cause an increase in our audit procedures, which at times leads to higher fees." (Assistant Manager B)

"Usually, the more workload an assignment has, the higher is its audit fee." (Senior Auditor D)

"Have to perform slightly more procedure for presentation of work done, hence... yes, higher fee charged due to more work required." (Mr G)

"The more audit procedure performed, the more cost incurred and thus the more fee is to be charged." (Senior Auditor $\mathrm{H}$ )

"Should the workload increase, so will the time spent on the engagement, and hence audit fee increases." (Assistant Manager J) 
In addition, three of the respondents claimed that $A O B$ also check on the hours charged and staff involvement in the engagement in order to ensure that the audit fee is not over or under charged, this is because it may affect the independence of the firm. They commented that:

"...AOB actually checked the hours charged and staff involvement in the job when they perform quality review of the audit. This will prevent firm from over/under charging the client or impacting firm independence due to high fee reliance on certain clients". (Senior Auditor S)

The interview results appear to suggest that audit fees charged to the clients are influenced by a few factors, and not directly affected by the establishment of AOB. However, when more work are done to ensure compliance to the standards as required by $A O B$, more hours are spent, more audit effort are put in, more audit fees will be charged to the clients.

\subsubsection{How does the establishment of $A O B$ affect the audit documentation?}

The respondents were also asked about how the establishment of $A O B$ affect their audit documentation. Most of them agree that the documentation has increased in volume after the establishment of $A O B$ by stating that:

"Additional documentation is included to resolve the points that AOB might raise or concern of." (Senior Auditor F)

"...yes, more work done....More detail explanations so that $A O B$ understand and make sure no careless mistakes occur in the working papers". (Senior Auditor L)

"Yes. We introduced documentations for work that we have performed previously but never documented (e.g. documentation on our reliance on electronic evidence, documentation on our understanding on client's process of identifying related party transactions)." (Senior Auditor P)

"Yes, more documentation need to be done." (Senior Auditor N)

In addition, the respondents also admitted that the practice review exercises by AOB have in some ways improved the quality of their audit documentations. They cited that:

"...AOB puts the audit profession under increased scrutiny. Nevertheless, AOB has highlighted concerns which have always been key risk areas identified by audit teams, and these keep us on our toes and really get our attention." (Assistant Manager B)

"...Yes. All findings and facts gathered will be documented.... More proper documentation". (Senior Auditor O)

"Yes. The audit working paper had been improved in order to obtain sufficient and appropriate audit evidence. All the work are done and covered in the audit working papers to comply with the ISA...... Our documentation and filings become complete and systematic." (Assistant Manager R)

"Yes.... Various improvements are done.... Our methodology Department in the firm takes notes on the weaknesses highlighted by $A O B$ and study them and incorporates steps to overcome the weakness, into our working paper........AOB acts as a watchdog and as such, every engagement has an equal chance of being selected by the Board to be reviewed, ...usually the large companies will be selected. Thus, the firm will always be alert, sceptical and professional in providing the highest standard of audit quality and working papers". (Assistant Manager J)

Senior Auditor $\mathrm{H}$, who is from one of the big four firms states that:

"Perhaps the establishment of $A O B$ would be more important to the small firms and not big four. Big four audit documentation is always improving, depending on how detailed the managers and partners are, how detailed are the staff performing the work documenting it. With or without $A O B$, our documentation will still be detailed."

This is supported by Senior Auditor A, who is also from the big four firms. He posits that:

"Not much impact as the firm always has its own documentation to carry out in fulfilling the requirements. The acceptable policy in our firm is improved from time to time in order to be compatible. The company always provides us with the latest information and documentation to be incorporated in our working papers". 
The findings in this study appear to suggest that the establishment of AOB affect the auditors' documentation of working papers, in terms of quantity and quality. The external auditors will strive to improve their working papers to be competitive and avoid the negative issue highlighted by the quality review committee. Another plausible explanation to this finding may also due to the auditors reactions to the $A O B$ reports in 2011 and 2012 which highlighted that auditors occasionally fail to document adequate supporting documents in their audit engagement files and other relevant evidences to support their opinion (Yeap, 2012). In addition, this finding shows that big four firms appear to have the monitoring procedures on working papers in place, and exercise continuous improvement in their firms as time progress, and their audit staff are kept updated.

\subsubsection{Does the establishment of $A O B$ affect the external auditors' reliance on internal auditors?}

The respondents were also asked whether the establishment of $A O B$ which requires them to do more audit procedures and put more audit effort prompt them to use and rely more on the internal auditors of the client companies. All of them claimed that their reliance on the internal auditors is not affected by $A O B$ establishment. These are their replies:

"Nope. The establishment of $A O B$ does not affect the reliance on internal audit function." (Assistant Manager R)

"No, as we generally place very little or no reliance on the internal audit functions." (Assistant Manager J)

"Not much, as it still depends on whether the internal audit function has the data that we need." (Senior Auditor. D)

"Doesn't affect much. Reliance of internal audit function will be depending on their scope of work done and relevance to audit." (Senior Auditor F)

"Doesn't affect much, except for the part where reasonable reliance on internal control can help audit procedure to be performed more smoothly." (Senior Auditor G)

Senior Auditor T, who is from one of the big four firms explained that justification for reliance on internal audit would be more robust. Among others, the factors considered are the competency of internal auditors, the qualification of internal auditors and the independence of internal audit department, and this has been the practice with or without AOB. Senior Auditor S supports him and explains that even though relying on internal audit function can reduce the audit effort, they still need to evaluate the work of internal audit which sometimes may indirectly increase their workload. Another senior auditor, Senior Auditor M added that, less efficient internal audit function would eventually lead to more work as more extra work and tests needed to be done to evaluate the internal audit function.

The interview results appear to suggest that $A O B$ establishment does not affect the external auditors' reliance on the internal auditors. This is because their reliance on the internal auditors would depend on the competence and experience of the internal auditors, as well as the independence of internal audit department. And if they decide to rely on the work, they still need to check the work of internal auditors before relying on it, which at times may cause them to do more testing.

\subsubsection{Does the establishment of $A O B$ affect the external auditors' meetings with their clients?}

Auditors normally would have meetings with their clients to discuss and solve issues relating to the audit. The respondents were asked if $A O B$ establishment has caused them to have more matters to solve, thus lead to more discussions and meetings with their clients compared to before its establishment. They have mixed feeling relating to this, some of them agree and some of them deny that $A O B$ establishment affect their meetings. Some respondents claim that their formal meetings with the audit committee are not affected, but they have more informal meetings with their clients. In addition, some respondents claim that they have more questions and request more information during meetings to achieve the quality auditing standards. They also claimed that the agenda of meetings have additional focus on those issues highlighted by AOB. They commented that: 
"Disputes are tabled for discussions with follow up procedures performed to determine courses of action to be taken....no change.....In most cases, frequency of meetings is constant year in year out. .....Normally highlights from $A O B$ are tabled for discussion which definitely increases the agenda of meeting." (Assistant Manager $B$ )

"No and yes..... Informal meeting with client will be held more but not formal meeting. Informal meeting means more frequency of communication with clients, eg. phone calls, emails, etc....And after the establishment of $A O B$, there are points highlighted during meetings to ensure compliance with the standards required by AOB." (Senior Auditor $G$ )

"Yes. To discuss more often and to settle the dispute." (Senior Auditor H)

"..yes, more meetings.... after $A O B$, we have additional focus especially on issues raised by $A O B$ " (Senior Auditor N)

"Indirectly yes... we have more meetings.... as we now require more information to achieve the quality auditing standards. Understanding and disputes can be solved by sorting out and have everyone on the same page through face to face meeting" (Senior Auditor S)

The interviews findings appear to suggest that establishment of $A O B$ affect the external auditors meetings with their clients to certain extend. In order to ensure that the audit works managed to be completed and opinion can be issued on time, all the disputes need to be resolved. In addition, the auditors also need to ensure that all the areas that have been or may be highlighted by AOB during its practice review are covered as prescribed in ISQC 1, more matters and information need to be obtained from the clients, thus more meetings, especially the informal meetings are carried out with the clients.

\subsubsection{How does the establishment of $A O B$ affect the audit opinion given to the client?}

After the establishment of $A O B$, prior study claims that litigation risk is expected to be higher, which in turn causes the auditors to be more willing to provide a qualified audit report for financial distressed firms (Habib, 2013). The respondents were asked about how the establishment of AOB affect the audit opinion given to their audit client. These are some of the replies from the respondents who think that the opinion given to the client's financial statement has become stricter after the existence of $A O B$ :

"...Yes...... as there is also strict policy in the firm now." (Senior Auditor A)

"...auditors now ensure that all of key risk area has been sufficiently audited before issuing an appropriate audit opinion" (Senior Auditor S)

" ...audit documentation or testing procedure are now must be in line with $A O B$ requirement........ Thereafter, audit testing will be stricter to derive at the audit opinion." (Senior Auditor F)

However, some of the respondents from big four firms claim that there is no impact on the type of opinion given after the establishment of $\mathrm{AOB}$. According to them, the opinion given is always based on true and fair of the financial statement after thorough audit procedures carried out, regardless of whether $A O B$ exist or not. They commented that:

"In my opinion that $A O B$ establishment might not have much impact to Big 4 firms as compared to small firms, as the audit opinion given by Big 4 firms are after thorough and detailed audit procedures performed. ... From my experience, the opinion given is based on the true and fair of the financial statement - and not because of $A O B$. With or without $A O B$, opinion given would not change". (Senior Auditor H)

"No big impact.... But more comprehensive audit procedures performed to support the audit opinion issued" (Senior Auditor S)

"With or without the presence of $A O B$, opinions are given in compliance with ISA. $A O B$ is an over sighting board to ensure quality work by the auditors, opinion are given based on audit procedures (per ISA) and whether a company is in compliance with accounting standards, local law and regulations, and any other legislation.... If it is required, an emphasis of matter opinion will be issued whether or not AOB has highlighted it." (Senior Auditor T)

And, most of the respondents from non-big four claimed that there are impact on their procedures and testing after the establishment of $\mathrm{AOB}$. They commented that: 
"We conduct a special meeting to discuss and come out with the solutions to improve the deficiencies highlighted by $A O B$......Yes. The audit environment became stringent and auditors must form their opinion based on sufficient and appropriate audit evidence."( Assistant Manager R)

"Yes. More extensive work is done to cover those areas that might be omitted.... Revise audit program and manuals." (Senior Auditor E)

"Our technical department will brief the hightlighted issues and revised the audit working paper to overcome the issues." (Senior Auditor K)

The respondents were also asked about the effects and steps taken by their firms after they get the reports from $A O B$ review team. Most of the respondents think that quality of audit opinion given increase after $A O B$ announced the audit deficiencies in the client firm audited by their firms. They commented that:

"...Yes, especially for big firms to maintain their standards and their reputation, they will strive to be the first to improve or try hard not to be the one who get assessed negatively on their quality." (Senior Auditor G)

"Yes, it gives example and area of concerns for audit firms to focus on." (Senior Auditor N)

"Yes, more internal matters and issues will be brought up and this could enhance details disclosure in the audit report." (Senior Auditor C)

"Yes, more extensive work will be done to cover those areas that might be omitted." (Senior Auditor E)

"Yes, it ensures that the audit opinion corresponds to sufficient audit work performed." (Assistant Manager J)

"We will take note of this and improve our next year audit.... Highlight the matters to the team to improve next year audit. If the issue is significant it could be communicated to the entire firm." (Senior Auditor P)

Generally, the interview results appear to suggest that the auditors give their opinion based on the evidence they collected during the audit. However, with the establishment of $A O B$, they would ensure that all relevant evidence is collected to support their opinion as required by the standards. Failure to provide the evidence to the auditors may cause the clients' accounts to be qualified. In addition, the interview results are also consistent with prior studies which posited that, after AOB reported deficiencies in the inspection report, external auditors might be stricter on the compliance of financial statements with the financial reporting standards and strive to improve the credibility of their audit opinion (Gramling, Krishnan \& Zhang, 2011; Robertson \& Houston, 2010).

\section{Conclusion}

The objective of this study is to explore the impact of establishment of AOB on external auditors in relation to the audit fees charged to their client, audit opinion given, audit documentation, reliance on internal audit function, and the meeting between auditors and clients. The results indicate that $A O B$ establishment does not affect the external auditors' reliance on the internal audit work. However, they admit that their documentation increase in volume and quality after the establishment of AOB. The findings also suggest that audit fee is not directly affected by the establishment of AOB. But, as more works are done and more effort is put in, more fees are charged to the clients. They also indicate that more informal meetings are conducted to get more information and clarification from the clients, especially to solve the audit disputes and issues. The respondents are adamant that their audit opinion are not affected by the $\mathrm{AOB}$ establishment, however, if the clients fail to provide the relevant evidence needed to support the opinion, disqualified opinion may be issued.

There are some limitations in this study. Only twenty auditors were interviewed, this small sample cannot be generalised. Future studies should include more samples from Big four and non-big four firms. In addition, partners of the firms and practice review committee members may also be included as samples to get their views on $A O B$ establishment. Interviews also can be conducted with the internal auditors and financial statements preparers to examine the impact of $A O B$ establishment on them. 


\section{Referencias}

1. ALON, A., MENNICKEN, A. \& SAMSONOVA-TADDEI, A. (2019). Dynamic and limits of regulatory privatisation: Reorganizing audit oversight in Rusia. Organization Studies. Special Issue. 1-23. DOI: $10.1177 / 0170840619850587$

2. Antle, R. \& Nalebuff, B. (1991). Conservatism and Auditor-Client Negotiations. Journal of Accounting Research. 29(Supplement). 31-54.

3. AOB ANNUAL REPORT, 2010. Retrieved on 17 October 2015, from http://www.sc.com.my/post_archive/2010-aob-annual-report/

4. AOB ANNUAL REPORT, 2011. Retrieved on 17 October 2015, from http://www.sc.com.my/post_archive/2011-aob-annual-report/

5. AOB ANNUAL REPORT, 2012. Retrieved on 17 October 2015, from http://www.sc.com.my/post_archive/2012-aob-annual-report/

6. AOB ANNUAL REPORT, 2013. Retrieved on 17 October 2015, from http://www.sc.com.my/post_archive/2013-aob-annual-report/

7. AOB ANNUAL REPORT, 2014. Retrieved on 17 October 2015, from http://www.sc.com.my/post_archive/2014-aob-annual-report/

8. AOB ANNUAL REPORT, 2015. Retrieved on 10 October 2018, from http://www.sc.com.my/post_archive/2015-aob-annual-report/

9. AOB ANNUAL REPORT, 2016. Retrieved on 10 October 2018, from http://www.sc.com.my/post_archive/2016-aob-annual-report/

10. AOB ANNUAL REPORT, 2017. Retrieved on 12 February 2021, from https://www.sc.com.my/api/documentms/download.ashx?id=b1b07a7f-8ce0-4db7-9bcff87f7e5965b2

11. AOB ANNUAL REPORT, 2018. Retrieved on 12 February 2021, from https://www.sc.com.my/api/documentms/download.ashx?id=741a5db9-949f-4212-bc15$556 \mathrm{e} 1 \mathrm{f} 338 \mathrm{~b} 7 \mathrm{a}$

12. AOB ANNUAL REPORT, 2019. Retrieved on 12 February 2021, from https://www.sc.com.my/api/documentms/download.ashx?id=639a71bd-a1e6-4177-a305a6b07d3cada0

13. BAME-ALDRED, C.W., BRANDON, D.M., MESSIER, W. F., RITTENBERG, L. E. \& STEFANIAK, C. M. (2013). A Summary of Research on External Auditor Reliance on the Internal Audit Function. Auditing: A Journal of Practice \& Theory. 23(1). 251-286.

14. BATHER, A. \& BURNABY, P. (2006).The Public Company Accounting Oversight Board: national and international implications. Managerial Auditing Journal. 21(6). 657-669.

15. BECK, A.K., FULLER, R.M., MURIEL, L. \& REID, C.D. (2013). Audit Fees and Investor Perceptions of Audit Characteristics. Behavioral Research in Accounting. 25(2). 71-95.

16. DEFOND, M.L. (2009). How should the auditors be audited? Comparing the PCAOB Inspection with the AICPA Peer Reviews. Journal of Accounting and Economics. 49. 104-108.

17. EARWOOD, G.S. (2010). PCAOB: Is It Constitutional or Not?. Unpublished thesis, School of Management, Texas Woman's University.

18. EBRAHIM, A. (2009). Audit fee premium and auditor change: the effect of Sarbanes Oxley Act. Managerial Auditing Journal. 25(2). 102-121.

19. ENHANCING AUDIT QUALITY. (December 2008).Malaysia Institute of Accountants: Accountants Today. 21(12). 8-10.

20. FLOROU, A., \& SHUAI, Y. (2020). The Costs of Public Audit Oversight: Evidence from the EU, retreived on 13 February, 2021 from http://dx.doi.org/10.2139/ssrn.3595454

21. GIBBINS, M., MCCRACKEN, S.A. \& SALTERIO, S.E. (2005). Negotiations over Accounting Issues: The Congruency of Audit Partner and Chief Financial Officer Recalls. Auditing: A Journal of Practice \& Theory. 24(Supplement). 171-193. 
22. GOMEZ, M. (April 2010). Watching the Watchdogs. Malaysia Institute of Accountants: Accountants Today. 23(4). 6-11.

23. GRAMLING, A.A., KRISHNAN, J. \& ZHANG, Y. (2011). Are PCAOB-Identified Audit Deficiencies Associated with a Change in Reporting Decisions of Triennially Inspected Audit Firms?. Auditing: A Journal of Practice \& Theory. 30(3). 59-79.

24. HABIB, A. (2013). A Meta-analysis of the Determinants of Modified Audit Opinion Decisions. Managerial Auditing Journal. 28(3). 184-216.

25. HILARY, G. \& LENNOX, C. (2005). The credibility of self-regulation: Evidence from the accounting profession's peer review program. Journal of Accounting and Economics. 40. 211-229.

26. HUANG, H. \& CHONG, H. G. (2016). Audit and legal implication of PCAOB's inspections among BRIC, International Journal of law and Management. 58(2). 231-244

27. HOITASH, R., MARKELEVICH, A. \& BARRAGATO, C.A. (2007). Auditor Fees and Audit Quality. Managerial Auditing Journal. 22(8). 761-786.

28. ISQC 1. (2014). Retrieved on 18 May 2014 from http://www.ifac.org/sites/default/files/downloads/a007-2010-iaasb-handbook-isqc-1.pdf

29. Khan, N., Qureshi, M. I., Mustapha, I., Irum, S., \& Arshad, R. N. (2020). A systematic literature review paper on online medical mobile applications in Malaysia. International Journal of Online and Biomedical Engineering, 16(1), 63-82. https://doi.org/10.3991/ijoe.v16i01.12263

30. LATSHAW, C.A. (2004). SEC Approves Auditing Standard No. 3, "Audit Documentation". Bank Accounting \& Finance. 29-44.

31. LEE, T.H. \& ALI, A.M. (2008). Audit Challenges in Malaysia Today.Accountants Today.

32. LEVY, H.B. (2005). Audit Documentation: It's a Whole New World. The CPA Journal. 30-37.

33. LI, Y. (2010). The case analysis of the scandal of Enron. International Journal of Business and Management. 5(10).37-41.

34. MITRA, S., DEIS, D.R. \& HOSSAIN, M. (2009). The Association between Audit Fees and Reported Earnings Quality in Pre- and Post-Sarbanes-Oxley Regimes. Review of Accounting and Finance. 8(3). 232-252.

35. MYERS, M.D. (2009). Qualitative Research in Business \& Management. The Cromwell Press Ltd, Trowbridge, Wiltshire. Great Britain.

36. PAYNE, E.A. \& RAMSAY, R.J. (2008). Audit Documentation Methods: A Path Model of Cognitive Processing, Memory, and Performance. Auditing: A Journal of Practice \& Theory. 27(1). 151-168.

37. PCAOB, 2011 ANNUAL REPORT. Retrieved October 15, 2013, from http://pcaobus.org/About/History/Pages/default.aspx

38. RICH, J.S., SOLOMON, I. \& TROTMAN, K.T. (1997). Multi-auditor Judgement/Decision Making Research: A Decade Later. Journal of Accounting Literature. 16(1). 86-126.

39. ROBERTSON, J.C. \& HOUSTON, R.W. (2010). Investors' Expectations of the Improvement in the Credibility of Audit Opinions following PCAOB Inspection Reports with Identified Deficiencies. Accounting and the Public Interest. 10. 36-56.

40. SIMUNIC, D.A. (1980). The Pricing of Audit Services: Theory and Evidence. Journal of Accounting Research. 18(1). 161-190.

41. SOOK HWA, F. \& MUSTAPHA, M. (2015). Implication of the audit oversight board: external auditors' perspective. Journal of Management Info. 2(3). 1-4.

42. STUNDA, R. \& PACINI, C. (2013). The Shareholder Wealth Effects of Auditor Changes and Auditor Opinions: Does a Difference Exist in a Pre-SOX Versus Post-SOX Environment? Academy of Accounting and Financial Studies Journal. 17(4). 29-40

43. WAN-HUSSIN, W.N. (2018). A case of audit transparency. Malaysian Business. Retrived February 13, 2021 from http://www.oyagsb.uum.edu.my/outreach/article/62-articles/338-article-5

44. WAN-HUSSIN, W.N, BAMAHROS, H.M., \& SHUKERI, S. N. (2016). An analysis of the engagement partner busyness in Malaysia Pre- and Post- Establishment of Audit Oversight Board. Information, 19(10B). 4761-4766 
45. YEAP, C. (2012, April 26). AOB wants more "intelligent" audits. The Edge Financial Daily. Retrived October 24, 2013 from http://www.theedgemalaysia.com/highlights/212471-aob-wants-moreintelligent-audits.html

46. ZIMBELMAN, M.F. \& WALLER, W.S. (1999). An Experimental Investigation of Auditor-Auditee Interaction under Ambiguity. Journal of Accounting Research. 37(Supplement). 135-155. 